\title{
Isolated Adrenocorticotropic Hormone Deficiency Associated with Growth Hormone Deficiency and Empty Sella
}

\author{
Toshimitsu Hatazoe, Yoshio Murakami, Itsumi Umaki, Motoi Sohmiya, Hong-Yi Hu and Yuzuru Kato
}

\begin{abstract}
A 38-year-old man had an acute onset of consciousness loss, pyrexia and hyponatremia. Plasma Adrenocorticotropic Hormone (ACTH) and cortisol levels were low. Plasma ACTH failed to respond to corticotropin-releasing hormone $(\mathrm{CRH})$ and insulin-induced hypoglycemia whereas i.m. injection of ACTH-Z raised plasma cortisol. Plasma insulin-like growth factor-I (IGF-I) and urine growth hormone $(\mathrm{GH})$ concentrations were also low and plasma thyroid-stimulating hormone (TSH) level was rather elevated. Plasma IGF-I and TSH levels were not completely normalized by glucocorticoid (GC) replacement alone although plasma GH responses to pharmacological stimuli were normalized. The GC replacement in combination with daily s.c. injection of recombinant human GH (rhGH) not only normalized plasma IGF-I and IGFBP-3 levels, but also further lowered the plasma TSH level, possibly due to an increased $T_{4} / T_{3}$ conversion, which resulted in a beneficial change in body composition.
\end{abstract}

(Internal Medicine 34: 688-691, 1995)

Key words: recombinant human growth hormone, replacement, body composition, corticotropinreleasing hormone $(\mathrm{CRH})$

\section{Introduction}

It has been reported that isolated adrenocorticotropic hormone (ACTH) deficiency (ICD) (1) may be accompanied by deficiencies of other pituitary hormones. Impairment of growth hormone $(\mathrm{GH})$ secretion was noted in 20 to $30 \%$ of ICD patients and was normalized after glucocorticoid (GC) replacement therapy $(2,3)$.

In the present study, we report an adult male case with ICD associated with GH deficiency in whom GH secretion was carefully investigated before and after GC replacement with or without daily s.c. injection of recombinant human $\mathrm{GH}(\mathrm{rhGH})$.

\section{Case Report}

A previously healthy 38 -year-old man was brought to the local emergency hospital because of unconsciousness, pyrexia and vomiting. Laboratory data showed severe hyponatremia $(107 \mathrm{mEq} / \mathrm{L})$ and serum cortisol was not detectable (less than 1 $\mu \mathrm{g} / \mathrm{dl})$. These symptoms and signs were corrected by GC administration. He was transferred to our hospital for further examination.

On admission, his height was $168.5 \mathrm{~cm}$ and body weight (BW) was $53.5 \mathrm{~kg}$. His body temperature was $36.3^{\circ} \mathrm{C}$ and pulse rate was $68 / \mathrm{min}$. Blood pressure was $104 / 60 \mathrm{mmHg}$. Chest and abdomen were normal. Neurological examination failed to reveal abnormality. Axillary and pubic hair was preserved. No pigmentation was noted in the skin and oral mucous membrane.

Laboratory investigation revealed mild anemia $(\mathrm{Hb} 12.7 \mathrm{~g} /$ $\mathrm{dl}$ ) and low glycohemoglobin level $\left(\mathrm{HbA}_{1 \mathrm{c}} 3.9 \%\right)$. Serum $\mathrm{Na}$, $\mathrm{K}$ and $\mathrm{Cl}$ levels were $142 \mathrm{mEq} / \mathrm{L}, 4.0 \mathrm{mEq} / \mathrm{L}$ and $106 \mathrm{mEq} / \mathrm{L}$, respectively.

Endocrinological examination revealed low plasma ACTH and cortisol levels (less than $5 \mathrm{pg} / \mathrm{ml}$ and less than $1 \mu \mathrm{g} / \mathrm{dl}$, respectively). Plasma GH and insulin-like growth factor-I(IGFI) levels were considerably low and urine $\mathrm{GH}$ was undetectable (less than $3 \mathrm{pg} / \mathrm{ml}$ ). Plasma thyroid-stimulating hormone (TSH) level was elevated $(6.08 \mu \mathrm{U} / \mathrm{ml})$ while serum triiodothyronine $\left(\mathrm{T}_{3}\right)$ and thyroxine $\left(\mathrm{T}_{4}\right)$ levels were within the normal range. Plasma luteinizing hormone (LH), follicle-stimulating hormone (FSH), prolactin (PRL) and antidiuretic hormone (ADH) levels were all normal.

Plasma cortisol and urine 17-hydroxycorticosteroid (17OHCS) increased on the standard ACTH test (ACTH-Z $1 \mathrm{mg}$, i.m. for 3 days) from less than $1 \mu \mathrm{g} / \mathrm{dl}$ to $12 \mu \mathrm{g} / \mathrm{dl}$ and from 0.4 $\mathrm{mg} / \mathrm{day}$ to $14.9 \mathrm{mg} / \mathrm{day}$, respectively. However, plasma cortisol did not respond to the rapid ACTH test $\left(\mathrm{ACTH}_{1-24} 0.25 \mathrm{mg}\right.$, i.v.). Plasma ACTH and cortisol did not respond to such

From the First Division, Department of Medicine, Shimane Medical University, Izumo

Received for publication September 14, 1994; Accepted for publication March 29, 1995

Reprint requests should be addressed to Dr. Toshimitsu Hatazoe, the First Division, Department of Medicine, Shimane Medical University, 89-1 Enya-cho, Izumo 693 
provocative stimuli as corticotropin-releasing hormone (CRH), $\mathrm{CRH}+$ arginine vasopressin (AVP), $\mathrm{CRH}+$ lysine vasopressin (LVP), and repeated CRH and insulin-induced hypoglycemia (Table 1). Plasma LH, FSH and ADH well responded to LHreleasing hormone (LHRH) and 5\% $\mathrm{NaCl}$ infusion, respectively. Plasma TSH and PRL showed exaggerated responses to thyrotropin-releasing hormone (TRH) (Table 2).

High resolution computed tomography (CT) scan with enhancement and magnetic resonance imaging (MRI) examination showed an empty sella.

GH secretion was further evaluated by such provocative stimuli as GH releasing hormone (GRH), insulin-induced

Table 1. Basal and Stimulated Level of Plasma ACTH

\begin{tabular}{llcc}
\hline Stimulation & & $\begin{array}{c}\text { Basal value } \\
(\mathrm{pg} / \mathrm{ml})\end{array}$ & $\begin{array}{c}\text { Peak value } \\
(\mathrm{pg} / \mathrm{ml})\end{array}$ \\
\hline Insulin & $(0.05 \mathrm{U} / \mathrm{kg} \mathrm{BW}$, i.v. $)$ & 19 & 21 \\
$\mathrm{CRF}$ & $(100 \mu \mathrm{g}$, i.v. $)$ & 19 & 21 \\
$\mathrm{CRF}$ & $(100 \mu \mathrm{g}$, d.i.v. $)$ & 6 & 8 \\
Repeated CRF & $(100 \mu \mathrm{g}$, i.v. 3 days $)$ & 12 & 14 \\
$\mathrm{CRF}+\mathrm{AVP}$ & $(\mathrm{CRF}: 100 \mu \mathrm{g}$, i.v. & & \\
& AVP: $0.5 \mathrm{U}$, i.v. $)$ & 6 & 10 \\
$\mathrm{CRF}+\mathrm{LVP}$ & $(\mathrm{CRF}: 100 \mu \mathrm{g}$, i.v. & & 7 \\
& LVP: $10 \mathrm{U}$, i.m. $)$ & 5 & \\
\hline
\end{tabular}

ACTH: adrenocorticotropic hormone, AVP: arginine vasopressin, CRF: corticotropin-releasing factor, LVP: lysine vasopressin.

Table 2. Basal and Stimulated Levels of Other Pituitary Hormones

\begin{tabular}{|c|c|c|c|}
\hline Hormones & Provocation test & Basal value & Peak value \\
\hline $\mathrm{TSH}(\mu \mathrm{U} / \mathrm{ml})$ & TRH (0.5mg i.v.) & 6.31 & 47.53 \\
\hline \multirow[t]{2}{*}{ PRL (ng/ml) } & TRH (0.5mg i.v.) & 7.7 & 80.6 \\
\hline & $\begin{array}{l}\text { metoclopramide } \\
\text { (20mg i.v.) }\end{array}$ & 10.7 & 149.4 \\
\hline $\mathrm{LH} \quad(\mathrm{mIU} / \mathrm{ml})$ & LH-RH $(100 \mu$ g i.v. $)$ & 2.1 & 29.5 \\
\hline $\mathrm{FSH}(\mathrm{mIU} / \mathrm{ml})$ & LH-RH (100 $\mu$ g i.v.) & 2.7 & 6.5 \\
\hline $\mathrm{ADH}(\mathrm{pg} / \mathrm{ml})$ & $\begin{array}{l}\text { Hypertonic saline } \\
\text { infusion }(5 \% \mathrm{NaCl})\end{array}$ & 1.7 & 4.1 \\
\hline
\end{tabular}

ADH: antidiuretic hormone, FSH: follicle-stimulating hormone, LH: luteinizing hormone, LH-RH: luteinizing hormone-releasing hormone, PRL: prolactin, TRH: thyrotropin-releasing hormone, TSH: thyroid-stimulating hormone. hypoglycemia and insulin-propranolol stimulation before and after GC replacement. Before GC replacement, peak plasma GH levels after GRH, insulin-induced hypoglycemia and insulin-propranolol stimulation were $7.1 \mathrm{ng} / \mathrm{ml}, 2.5 \mathrm{ng} / \mathrm{ml}$ and 1.5 $\mathrm{ng} / \mathrm{ml}$, respectively. When these provocative tests were repeated 2 to 4 weeks after GC replacement (hydrocortisone 20 $\mathrm{mg} /$ day), peak plasma GH levels after GRH, insulin-induced hypoglycemia and insulin-propranolol were $13.3 \mathrm{ng} / \mathrm{ml}, 7.2 \mathrm{ng} /$ $\mathrm{ml}$ and $14.8 \mathrm{ng} / \mathrm{ml}$, respectively (Fig. 1).

Daily profiles of plasma $\mathrm{GH}$ were determined one month and 7 months after GC replacement (hydrocortisone $10 \mathrm{mg} /$ day). Plasma samples were obtained every 20 minutes and GH concentrations were determined by highly sensitive enzyme immunoassay (EIA) as described previously (4). There were some pulsatile increases in the night time plasma GH level, but the highest peak value was $4.7 \mathrm{ng} / \mathrm{ml}$ (one month) and $3.1 \mathrm{ng} / \mathrm{ml}$ (7 months), respectively. The mean plasma GH during 24 hours was $0.48 \mathrm{ng} / \mathrm{ml}$ (one month) and $0.63 \mathrm{ng} / \mathrm{ml}$ ( 7 months). During the GC replacement, low plasma IGF-I levels were maintained
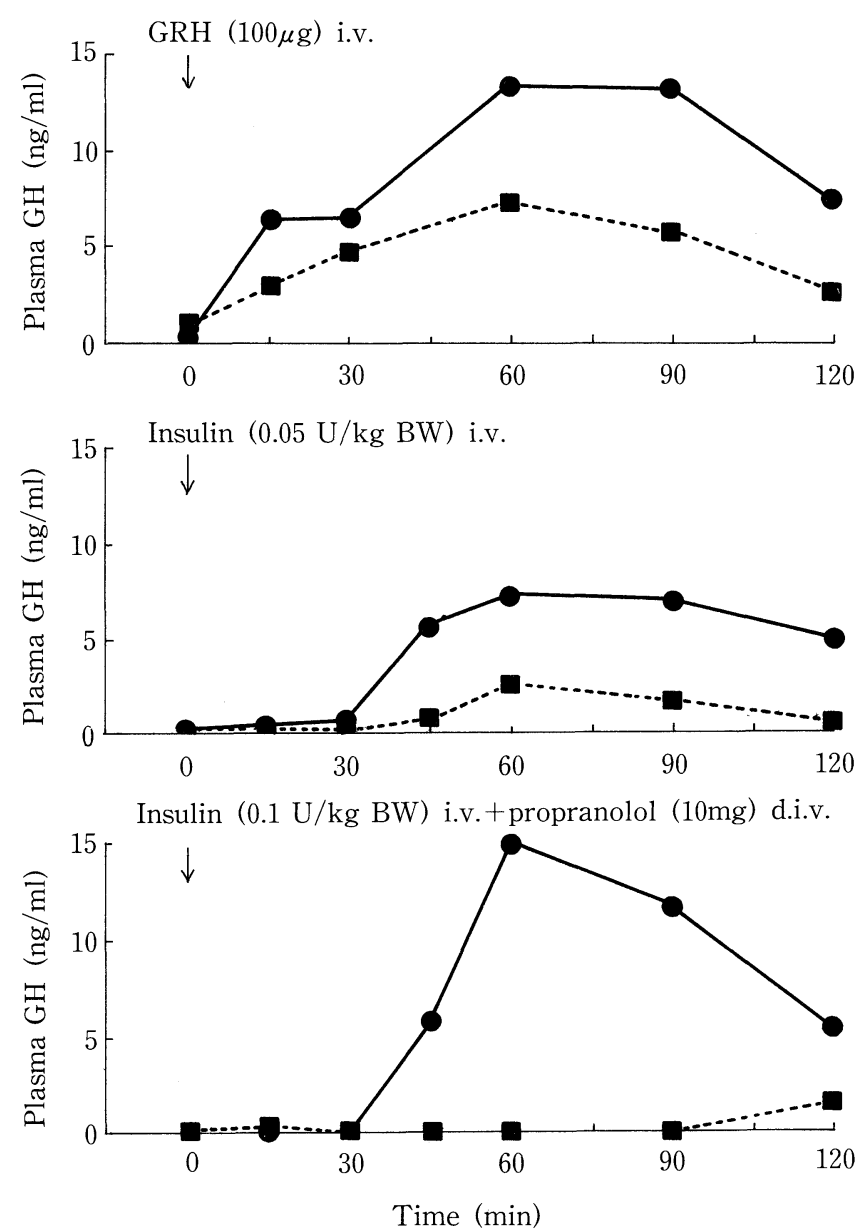

Figure 1. Plasma GH responses to GRH (100 $\mu$ g, i.v., top panel), insulin-induced hypoglycemia $(0.05 \mathrm{U} / \mathrm{kg} \mathrm{BW}$, i.v., middle panel) and insulin-propranolol (0.1 U/kg BW, i.v. + $10 \mathrm{mg}$. d.i.v.) test (bottom) before (- - ) and after (-) glucocorticoid replacement. 

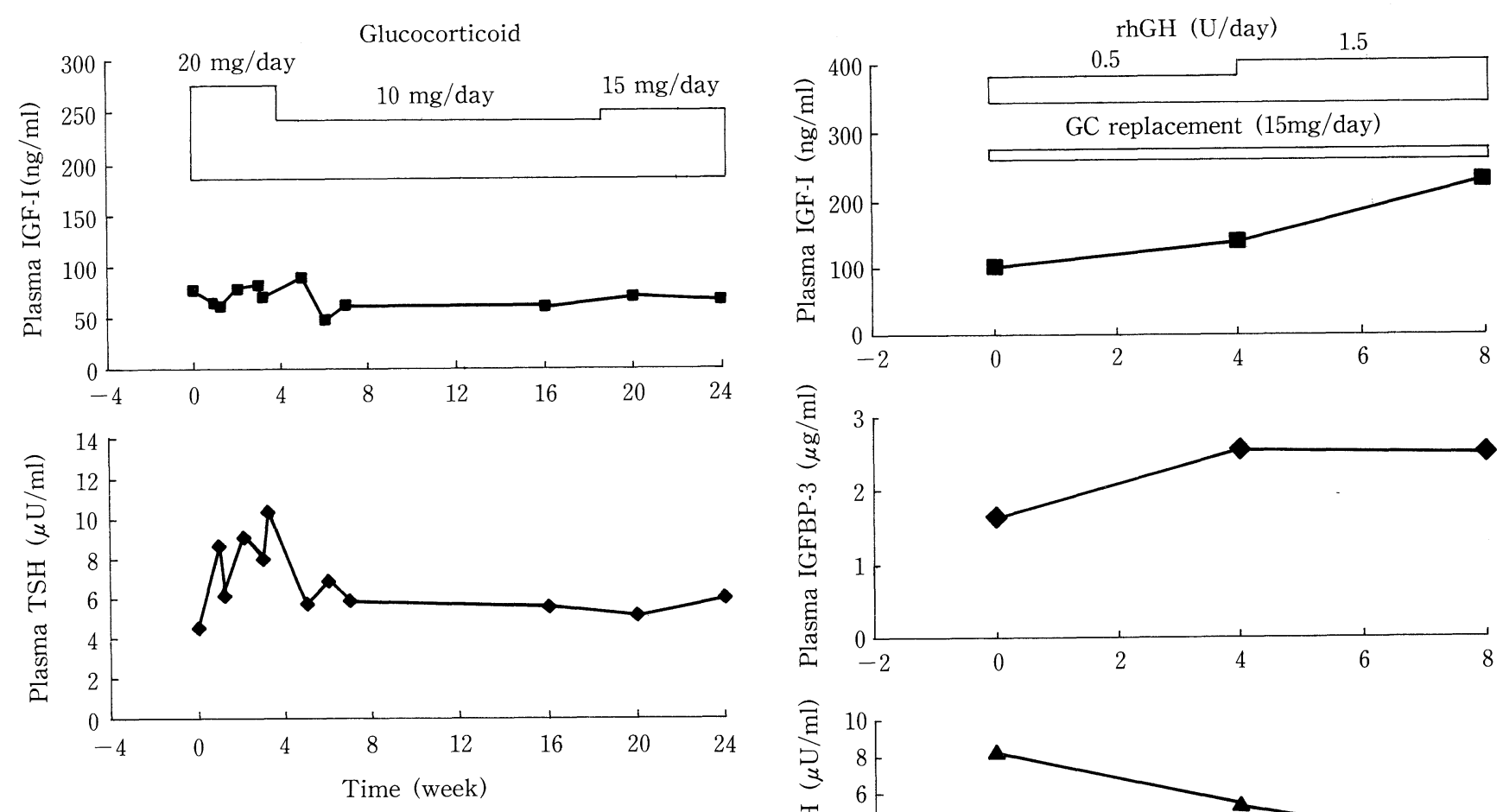

Figure 2. Plasma IGF-I and TSH levels after GC replacement therapy.

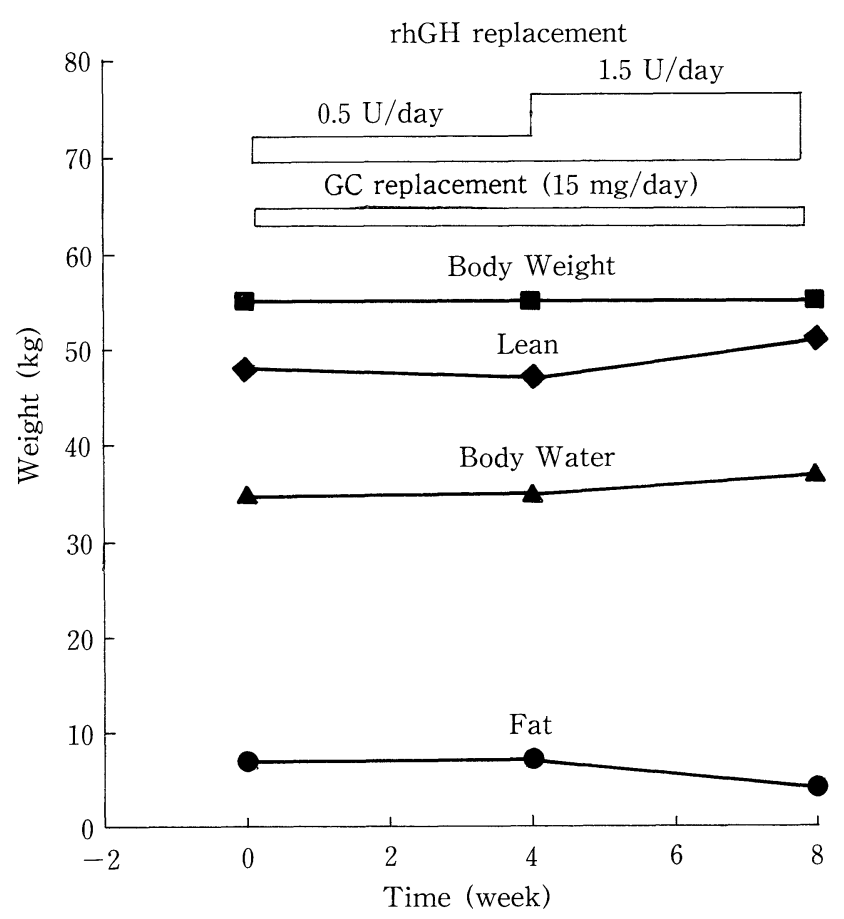

Figure 4. Changes in body composition during rhGH replacement. Body composition was analyzed by means of bioimpedance analysis (BIA) method.

(77 ng/ml) and plasma TSH remained high (Fig. 2). Serum $\mathrm{T}_{3}$ and free $\mathrm{T}_{4}\left(\mathrm{fT}_{4}\right)$ levels were not changed and urine $\mathrm{GH}$ excretion for 24 hours remained less than the minimal detect-
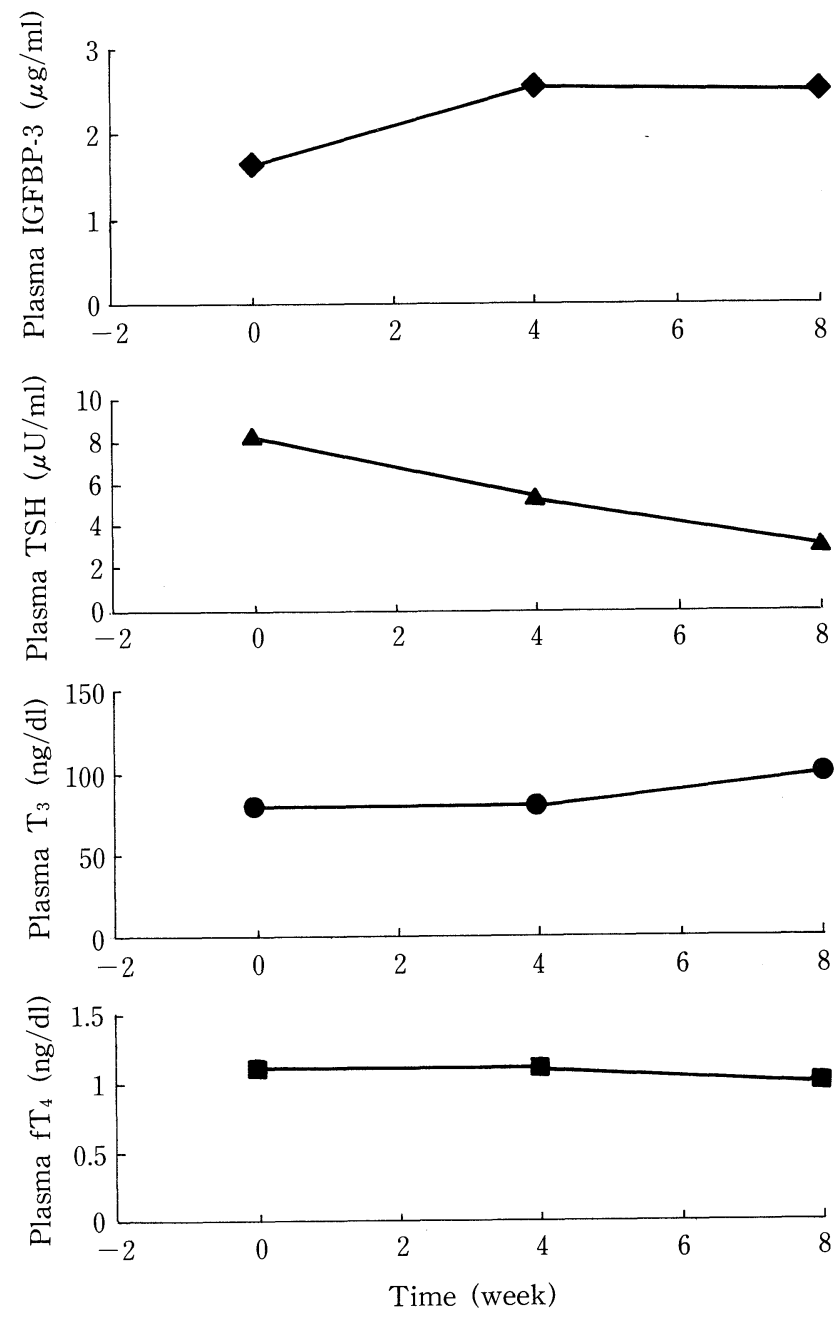

Figure 3. Plasma IGF-I, IGFBP-3, TSH, and serum $\mathrm{T}_{3}$ and $\mathrm{fT}_{4}$ levels after $\mathrm{rhGH}$ replacement therapy. Glucocorticoid was continuously replaced $(15 \mathrm{mg} / \mathrm{day})$.

able concentration $(0.3 \mathrm{pg} / \mathrm{ml})$ during $\mathrm{GC}$ replacement alone (data not shown).

We obtained written consent for the rhGH replacement therapy from this patient, and rhGH was injected daily s.c. (0.01 $\mathrm{U} / \mathrm{kg} \mathrm{BW}$; for the initial four weeks, followed by $0.03 \mathrm{U} / \mathrm{kg} \mathrm{BW}$ for the next four weeks) along with hydrocortisone. Plasma IGF-I and IGF binding protein-3 (IGFBP-3) were normally increased from $101 \mathrm{ng} / \mathrm{ml}$ to $230 \mathrm{ng} / \mathrm{ml}$ and $1.63 \mu \mathrm{g} / \mathrm{ml}$ to 2.48 $\mu \mathrm{g} / \mathrm{ml}$, respectively (Fig. 3). 


\section{GH Deficiency in ICD}

During the GC replacement therapy with rhGH, plasma TSH decreased from $8.3 \mu \mathrm{U} / \mathrm{ml}$ to $3.1 \mu \mathrm{U} / \mathrm{ml}$ while serum $\mathrm{T}_{3}$ levels increased from $80 \mathrm{ng} / \mathrm{dl}$ to $100 \mathrm{ng} / \mathrm{dl}$ without any considerable change in serum free $\mathrm{T}_{4}$ (Fig. 3 ). In addition, his lean body mass determined by bioimpedance analysis (BIA) (5) was increased from 48 to $51 \mathrm{~kg}$ whereas fat mass decreased from 7 to $4 \mathrm{~kg}$ (Fig. 4).

\section{Discussion}

GC exerts dual effects on GH secretion. Pharmacological doses of GC inhibit growth and plasma GH responses to provocative stimuli while GC enhances $\mathrm{GH}$ release at the pituitary level (6).

It has been reported that $\mathrm{GH}$ secretion is impaired in $20-30 \%$ of the patients with isolated ACTH deficiency $(2,3)$. Giustina et al (7) reported that GH deficiency in patients with idiopathic ACTH deficiency is resolved during GC replacement therapy and that short-term GC deprivation impairs the GH response to GRH in these patients, suggesting that physiological plasma cortisol levels are necessary for a normal plasma GH response to provocative stimuli.

In the present study, we demonstrated that the impaired $\mathrm{GH}$ response to provocative stimuli was partly corrected by GC replacement alone, whereas spontaneous GH secretion determined by 24 hours blood sampling was not normalized even after 7 months of GC replacement therapy. Plasma IGF-I and IGFBP-3 levels were normalized 4 weeks after daily s.c. injection of rhGH. An increase in serum $\mathrm{T}_{3}$ and a further decrease in plasma TSH were demonstrated in the course. It might be possible that $\mathrm{GH}$ and subsequently the normalized plasma IGF-I stimulated the peripheral conversion of $T_{4}$ to $T_{3}$ (8) and that the increased active hormone levels available thereby inhibited TSH secretion from the pituitary gland.

It is generally agreed that $\mathrm{GH}$ replacement therapy is beneficial for adult patients with GH deficiency. In the present patient, after 4 weeks of rhGH replacement, his lean body mass increased and fat mass decreased although his body weight was unchanged. These findings are the same as those of Whitehead et al (9), in that total body weight was not changed during rhGH treatment and that rhGH treatment had anabolic and lipolytic effects. Salomon et al (10) also reported beneficial effects of GH replacement on body composition and metabolism in a randomized double-blind placebo-controlled trial of rhGH administration in GH-deficient adults.

In summary, we report a case of ICD, in which GC replacement alone failed to restore normal GH secretion. Daily s.c. injection of rhGH resulted in beneficial effects such as normalization of plasma IGF-I and IGFBP-3 levels as well as promotion of conversion of $\mathrm{T}_{4}$ to $\mathrm{T}_{3}$ and a change in body composition.

\section{References}

1) Sternberg A, Shechter FR, Segal HI. True pituitary Addison's disease: a pituitary unitropic deficiency (fifteen-year follow up). J Clin Endocrinol 14: $1519,1954$.

2) Hashimoto K, Nishioka T, Iyota K, et al. Hyperresponsiveness of TSH and prolactin and impaired responsiveness of GH in Japanese patients with isolated ACTH deficiency. Folia Endocrinol 68: 1096, 1992.

3) Yamamoto T, Fukuyama J, Hasegawa K, Sugiura M. Isolated corticotropin deficiency in adults. Report of 10 cases and review of literature. Arch Intern Med 152: 1705, 1992.

4) Sohmiya M, Kato $Y$. Renal clearance, metabolic clearance rate and halflife of human growth hormone in young and aged subjects. J Clin Endocrinol Metab 75: 1487, 1992.

5) Hu H-Y, Yamamoto H, Sohmiya M, Abe T, Murakami Y, Kato Y. Body composition assessed by biochemical impedance analysis (BIA) and the correlation with plasma insulin-like growth factor I (IGF-I) in normal Japanese subjects and patients with acromegaly and GH deficiency. Endocr J 41: 63, 1994.

6) Adams EF, Brajkovich IE, Mashiter K. Growth hormone and prolactin secretion by dispersed cell cultures of human pituitary adenomas: longterm effects of hydrocortisone, estradiol, insulin, 3,5,3'-triiodothyronine and thyroxine. J Clin Endocrinol Metab 53: 381, 1981.

7) Giustina A, Romanelli G, Candrina R, Giustina G. Growth hormone deficiency in patients with idiopathic adrenocorticotropin deficiency resolves during glucocorticoid replacement. J Clin Endocrinol Metab 68: 120, 1989.

8) Pirazzoli P, Cacciari E, Mandini, et al. Growth and thyroid function in children treated with growth hormone. J Pediatr 121: 210, 1992.

9) Whitehead HM, Boreham C, McIrash EM, et al. Growth hormone treatment of adults with growth hormone deficiency: results of a 13month placebo controlled cross over study. Clin Endocrinol 36: 45, 1992.

10) Salomon F, Cuneo RC, Hesp R, Sonksen PH. The effects of treatment with recombinant human growth hormone on body composition and metabolism in adults with growth hormone deficiency. N Engl J Med 321: 1797, 1989. 